\title{
PERFORMANCE MEASUREMENT SYSTEMS: EMPIRICAL EVIDENCE FROM SLOVENIA
}

\author{
MARJAN ODAR ${ }^{1}$ \\ SLAVKA KAVČIČ $\check{C}^{2}$ \\ MATEJA JERMAN ${ }^{3}$
}

\section{ARTICLE INFO}

JEL classification: M41

Keywords:

- performance measurement system

- management accounting system

- transition economy
ABSTRACT

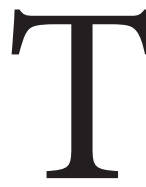

he present study aims to analyze the use of performance measurement systems within Slovene large, medium-sized, and small companies. The study was performed on the basis of a questionnaire which was distributed to the management of Slovene firms in 2007, analyzing the use of performance measurement techniques in the post-transition period. Slovene companies mainly use traditional performance measurement techniques. Contemporary performance measurement systems were used only occasionally. Moreover, the study demonstrates that performance measurement techniques differ between companies of different size. Small companies have less developed performance measurement systems that are based almost solely on traditional measurement techniques, while large companies have more developed performance measurement systems and also use some more contemporary techniques. Future research should analyze the design of management accounting systems in economies that have completed the transition period to provide evidence about the changes that occur afterwards.
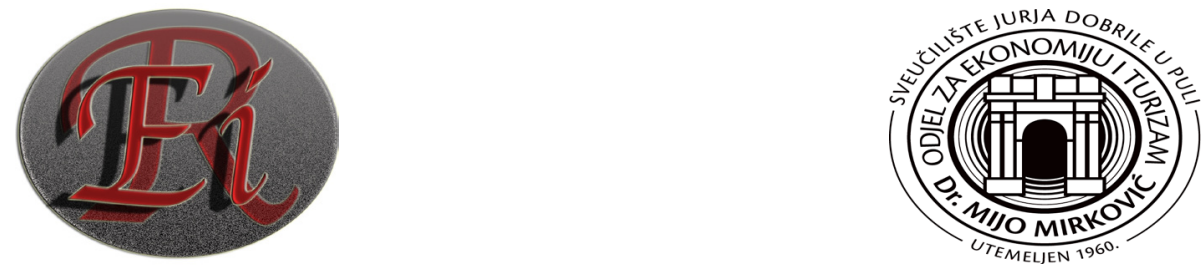

${ }^{1}$ Assistant Professor, PhD, University of Ljubljana, Faculty of Economics, tel.: + 386 (1) 58925 14, fax: + 386 (1) 5892698 , E-mail: marjan.odar@ef.uni-lj.si, Kardeljeva ploščad 17, 1000 Ljubljana, Slovenia.

${ }^{2}$ Full Professor, PhD, University of Ljubljana, Faculty of Economics, tel.: + 386 (1) 58925 14, fax: + 386 (1) 5892698 , E-mail: slavka.kavcic@ef.uni-lj.si, Kardeljeva ploščad 17, 1000 Ljubljana, Slovenia.

${ }^{3}$ Senior Lecturer, MSc, University of Primorska, Faculty of Management, tel: + 386 (5) 610 20 48, fax: +386 (5) 6102015 , Email: mateja.jerman@fm-kp.si, Cankarjeva 5, 6104 Koper, Slovenia. 


\section{INTRODUCTION}

In spite of the fact that many of the basic accounting principles were developed in 1920s, they remained largely unchanged until 1980s (Neely, 2005). The weaknesses of traditional accounting measures that were addressed in the late 1970s and 1980s resulted in the development of numerous performance measurement systems. This phenomenon was particularly present in the late 1980s and in the 1990s. The development of performance measurement systems can be divided into three main phases (Bourne et al., 2000, 757): a) the design of performance measures, b) the implementation of performance measures, and c) the use of performance measures. While the design and the implementation phases have been the subject of much research, the third phase has not been a subject of wider interest. The present study aims to make a contribution to the existing findings regarding the use of performance measurement systems in practice from the framework of a transition economy. The majority of studies deal with developed market economies, while just few of them were engaged in economies that are in the transition process, or have barely completed it (Haldma and Lääts, 2002) and the situation to date has not changed significantly (Hopper et al., 2009).

The views about the contribution of performance measurement systems to organizational performance are not uniform among researchers. Some of them demonstrated that businesses performed better if they used integrated performance measures, while others argue that the use of performance measurement systems, such as balanced scorecard does not make any difference to business performance (Bititci et al., 2006). More contemporary studies suggest that the impact of performance measurement systems is contingent (Braam and Nijssen, 2004). Deriving from the contingency theory, the benefits of performance measurement systems depend on the way they are used. Thus, we believe that an appropriate performance measurement system as an integral part of a management accounting system is also crucial in Slovenia.

The remainder of this paper is organized as follows. Section Two is a brief overview of the literature on performance measurement systems in which traditional and contemporary techniques for decision making are presented. The third part explains the data used for the analysis and the methodology. The results of the analysis follow in the fourth part. Finally, the paper ends with concluding remarks.

\section{THEORETICAL BACKGROUND AND HYPOTHESIS FORMULATION}

The literature review reveals that much of the early research in the field of performance measurement in management accounting was concerned with either the use of performance measures or the use of standard costing and variance analysis (Chenhall and LangfieldSmith, 2007). It is argued that performance measurement has an important role in efficient and effective management of organizations. Already Emmanuel, Otley and Merchant (1990) noted that performance evaluation was an important function of management accounting. Despite the fact that substantial efforts were made to what should be measured today, no uniform comprehensive measurement system that could be adopted universally has yet been formulated. Studies have shown (Chenhall and Langfield-Smith, 1998; Joshi, 2001) that the 
most widely used among performance measures were at first financially-oriented techniques, and only later non-financial measures became notable more important. McKinnon and Bruns (1992) found that among almost 100 financial and non-financial measures they were exploring in US companies, profit and income were the most widely used measures to evaluate company performance. Among the ratios, the most commonly examined is the return on equity (ROE), followed by the return on assets (ROA) and the leverage (ROE components in the DuPont formula) (Lapointe-Antunes, Cormier and Magnan, 2010, 41). DuPont has been widely acknowledged to be the founder of the financial ratios measurement system (Anderson and McAdam, 2004). From early 1900, when the system was presented for the first time, until 1980s it was the most widely used performance measurement system to benchmark organizational performance. Due to the fact that profit as a simple accounting measure relies on past results and, moreover, can be subject to earnings management, traditional accounting measures were supplemented by non-financial categories, with an emphasis on future performance instead of past results.

By the early 1980s there was a growing realization that financial profit measures failed to reflect changes in the competitive circumstances and strategies of modern organizations (Kennerley and Neely, 2002, 1223). In recent decades we have seen numerous attempts to create more dynamic models for measuring business results, but scant interest has been shown by those involved in the practice of management accounting. The most notable innovation in this field was undoubtedly the balanced scorecard (BSC) developed by Kaplan and Norton (1992). Many other attempts were made to evaluate performance measurement systems. Among those attempts were the performance measurement matrix by Keegan, Eiler and Jones in 1989, the performance pyramid proposed by Lynch and Cross (1991), the results and determinants framework which emerged in 1991 (Fitzgerald et al., 1991), and the performance prism in 2001 (Neely, Adams and Crowe, 2001). Different models address different issues. None of these frameworks (apart from the BSC) was widely accepted in practice. In the 2000s a lot of research emphasizes the need to re-evaluate the existing performance measurement systems (Bourne et al., 2000; Bititci, Turner and Begemann, 2000). Bitici, Turner and Begemann (2000) criticism mostly refers to the dynamicity of the systems. They believe that modern systems should be sensitive to changes in the internal and external environments. Changes in the environment should lead to reviewed internal objectives and, finally, the revised objectives should be reallocated to the critical parts of the system.

Research from less developed countries and transition economies (Haldma and Lääts, 2002; Hopper et al., 2009) have demonstrated that management accounting systems are still not highly developed and comparable with developed market economies, and they are still in the initial stages of development. Joshi (2001) found out that in the case of India the adoption rate of traditional accounting practices was higher than (for that time) recently developed techniques. Moreover, he found that in the case of India most of the practices adopted relate to traditional budgeting and performance evaluation system. The predominant use of traditional management accounting techniques was also found by Sulaiman, Ahmad and Alwi (2004) in the case of Malaysia, Singapore, China, and India.

Since our study explores the use of performance measurement systems and refers to a period when Slovenia was in the post transition process (for details see Stubelj and Dolenc, 2010), we formulate our first hypothesis as follows: Slovene companies mostly use traditional performance measurement techniques. Traditional management accounting techniques were more financially-oriented, focusing on variance analysis and profit-based performance 
measures (Chenhall and Langfield-Smith, 1998, 1), while modern management accounting techniques focus more on non-financial measures (for more details see Ivankovičc, Janković and Peršić, 2010), using contemporary performance measurement systems and benchmarking techniques.

Performance measurement systems proposed by academics and practitioners were developed for large companies. Small and large companies are fundamentally different from each other in three central aspects: uncertainty, innovation, and evolution (Garengo, Biazzo and Bititci, 2005, 26). Differences between performance measurement systems in large and small companies were rarely addressed. Garengo, Biazzo and Bititci $(2005,28-29)$ found five common characteristics of performance measurement systems in small and medium-sized companies (SMEs): a) Difficulties in involving SMEs in performance measurement projects, b) SMEs either do not use any performance measurement model or they use models incorrectly, c) Performance measurement systems implemented in SMEs rarely have a "holistic approach," d) SMEs' approach to performance measurement is informal, not planned and not based on a predefined model, and e) SMEs have limited resources for data analysis.

Performance measurement systems should help small and medium-sized entities manage uncertainty, innovate their products and services, and sustain evolution and change processes (Garengo, Biazzo and Bititci, 2005, 26). Performance measurement systems developed in theory don't seem to apply to small companies (Cocca and Alberti, 2010). Moreover, Hudson, Smart and Bourne (2001) found that small companies had difficulties in implementing a strategic performance measurement system. Researchers suggest (Hudson, Smart and Bourne, 2001; Garengo, Biazzo and Bititci, 2005) that the primary reasons are lack of human resources and managerial expertise. In relation to different characteristics of companies, depending on their size, we believe that: performance measurement practices differ in relation to the size of the company.

\section{RESEARCH SAMPLE AND METHODOLOGY}

Our analysis is performed on the basis of a questionnaire that was distributed to large, medium, and small-sized Slovene companies at the beginning of 2007. 167 questionnaires were correctly completed. The questionnaire (close-ended questions) was formulated on the basis of the Slovene Accounting Standards (SAS). The majority of companies that were asked to complete the questionnaire were reporting in accordance with the SAS, and only a minority had introduced the International Financial Reporting Standards (IFRS) which have become obligatory for consolidated accounts of publicly traded companies since 2005. Thus, we based our questionnaire on the rules concerning professional conduct in the field of accounting as defined by the SAS. Due to the fact that none of the SAS define rules concerning professional conduct in the field of management accounting, we based the questionnaire on SAS No. 29 Accounting analysis, focused on the overall operation analysis of the entity. In general, SAS 29 defines two main methods of analysis: a) analysis of variances (no detailed rules are provided), and b) financial ratios analysis. We focused on leverage ratios, liquidity ratios, and turnover ratios. SAS 29 as leverage ratios includes: equity financing rate, debt financing rate, long-term financing rate, short-term financing rate, share capital rate, debt to equity ratio, and rate of accrued and deferred items. Liquidity ratios are cash (acid test) ratio, quick ratio, and current 
ratio, while turnover ratios are current assets turnover ratio, fixed assets turnover ratio, and materials inventory/products/merchandise inventory/trade receivables turnover ratio.

The financial aspect is measured on the basis of profitability measures, while the economic indicators focus on how the economic status of stakeholders changes over time (as a consequence of organizational activities).

In order to test the first hypothesis, we analyzed performance measurement techniques used by Slovene companies to evaluate business performance. The second hypothesis was tested with chi-square tests, where differences between companies of different sizes were ascertained.

\section{DATA ANALYSIS AND RESULTS}

The sample consists of 167 companies, of which $36.5 \%$ are large companies, $33.5 \%$ medium, and 30\% small-sized companies. ${ }^{4}$ 57.5\% are operating in services industry, while 42.5\% are manufacturing companies. In 2006, 148 companies (88.6\%) recorded a positive return on equity, while 19 (11.4\%) recorded losses. Characteristics of accounting departments and the education of accountants in companies that were included in the analysis are presented in Table 1.

\begin{tabular}{|c|c|c|c|c|c|c|c|c|c|c|}
\hline \multicolumn{3}{|c|}{ Company Size } & \multicolumn{2}{|c|}{ Accounting } & \multicolumn{2}{|c|}{ Department } & \multicolumn{4}{|c|}{ Education } \\
\hline & $\mathrm{n}$ & $\%$ & I & $\mathrm{E}$ & $\mathrm{A}$ & $\mathrm{N}$ & $\mathrm{S}$ & $\mathrm{C}$ & $\mathrm{H}$ & M \\
\hline Large & 61 & $36.5 \%$ & 61 & l & 58 & 3 & 7 & 12 & 37 & 5 \\
\hline $\begin{array}{l}\text { Medium- } \\
\text { sized }\end{array}$ & 56 & $33.5 \%$ & 55 & 1 & 54 & 1 & 7 & 13 & 33 & 3 \\
\hline Small & 50 & $30 \%$ & 38 & 12 & 34 & 4 & 13 & 13 & 24 & 0 \\
\hline Total & 167 & $100 \%$ & 154 & 13 & 146 & 8 & 27 & 38 & 94 & 8 \\
\hline
\end{tabular}

To understand more in-depth the organization of accounting departments in Slovene companies and the use of performance measurement systems in practice, the most important general characteristics of accounting departments are presented. In the presented sample $91 \%$ of the companies had its own accounting department, while $8 \%$ used an external accounting service. Among those that do not have their own accounting department (13 companies) twelve

\footnotetext{
${ }^{4}$ In accordance with the Slovene Companies Act from the year 2006 companies are classified as micro, small, medium-sized, and large companies on the basis of the following criteria at the balancing date of the annual balance sheet (on the basis of the data for two consecutive business years): the average number of employees in a financial year, net sales income; and the value of assets. Micro companies are those that have less than 10 employees, net sales income less than 2 million $€$, value of assets less than 2 million $€$. Small companies are those that have less than 50 employees, net sales income less than $8,800,000$ million $€$, value of assets less than 4,400,000 million $€$. Medium-sized companies are those that have less than 250 employees, net sales income less than $35,000,000$ million $€$, value of assets less than 17,500,000 million $€$. Companies that do not comply with the criteria for micro, small, or medium-sized companies are large companies. For more detailed criteria see: http://www.mg.gov.si/fileadmin/ mg.gov.si/pageuploads/predpisi/ZGD-1_prevod_AN.pdf.
} 
companies are small, and one is a medium-sized company. The results are consistent with those expected. Practically, only small companies had external accounting services. Among companies that have their own accounting service, the majority has a separate accounting department within the company. In only 8 or $5.2 \%$ of the cases (out of 154) accounting services are held within other departments. Most of chief accounting officers finished a higher education program (94 or 56.3\%), followed by those that finished a vocational college (38 or $22.8 \%$ ), secondary school education ( 27 or $16.2 \%$ ), and only 8 (or $4.7 \%$ ) have a master degree. However, chi-square test suggests that the education of the chief accounting officer does not differ among the companies of different size $\left(\chi^{2}\right.$-value of $\left.9.574 ; \mathrm{p}=0.144\right)$. Moreover, most of the chief accounting officers are not certified by the Institute of Auditors (not presented in Table 1). In the case of large companies this share amounts to $73.8 \%$ (or 45 companies), in medium-sized companies to $73.2 \%$ (or 41 companies), and in small companies to $66 \%$ (33 companies). The results of the chi-square test do not indicate any significant difference between the companies of different sizes ( $\chi^{2}$-value of 7.446; $\left.p=0.489\right)$.

In accordance with the literature, information for decision makers (including those that concerns performance measurement) is provided by the management accounting system. Thus, we first analyzed the importance of accounting departments as the primary source of decision-making information. Companies were asked which department or group of employees provided the information for decision making (Table 2).

TABLE 2 - Departments and group of employees providing information for decision-makers

\begin{tabular}{|c|c|c|c|c|}
\hline $\begin{array}{l}\text { Departments } \\
\text { and group of } \\
\text { employees }\end{array}$ & Large & $\begin{array}{l}\text { Medium- } \\
\text { sized }\end{array}$ & Small & $\begin{array}{l}\text { Total } \\
\text { (\% of } \\
\text { total) }\end{array}$ \\
\hline Accounting & 18 & 27 & 30 & $\begin{array}{c}75 \\
(45 \%)\end{array}$ \\
\hline Analysts & 5 & 2 & 2 & $10(6 \%)$ \\
\hline $\begin{array}{l}\text { Operational } \\
\text { staff }\end{array}$ & 1 & 5 & 4 & $10(6 \%)$ \\
\hline $\begin{array}{l}\text { Accounting } \\
\text { and some } \\
\text { other } \\
\text { departments }\end{array}$ & 30 & 20 & 10 & $\begin{array}{c}60 \\
(36 \%)\end{array}$ \\
\hline Other & 7 & 2 & 3 & $12(7 \%)$ \\
\hline $\begin{array}{l}\text { Total } \\
\text { (\% of total) }\end{array}$ & $\begin{array}{c}61 \\
(36.5 \%)\end{array}$ & $\begin{array}{c}56 \\
(34 \%)\end{array}$ & $\begin{array}{c}49^{*} \\
(29.5 \%)\end{array}$ & $\begin{array}{c}167 \\
(100 \%)\end{array}$ \\
\hline $\begin{array}{l}\text { Chi-square } \\
\text { test }^{\star \star}\end{array}$ & \multicolumn{4}{|c|}{$\mathrm{X}^{2}$-value of $12.531 ; p=0.002$} \\
\hline
\end{tabular}

SOURCE: Own data

Notes*: 1 small company did not provide any answer

Notes $^{* *}$ : For the purpose of the chi-square test, only the accounting department and the combination between accounting department and other departments were included (cell categories with an expected count below 5 were excluded). 
The results show that the accounting department is on average the most important department providing information for decision makers in Slovene companies ( $45 \%$ of cases). It is followed by the combination of accounting department and other departments (36\% of cases). In the case of large companies, the most important provider of information is the combination of accounting department and other departments (30 companies out of 61, i.e. $49 \%$ ), while in middle-sized and small companies the most important is the accounting department per se, followed by the combination of accounting and other departments. The chi-square test suggests that the importance of departments differs between companies in relation to their size ( $\mathrm{p}<0.05)$. Operations of large companies are more complex and the same is true of information for decision makers. Thus, it is not surprising that in large companies decision-makers most commonly receive information provided by the combination of the accounting and other departments (combination of different knowledge).

To ascertain if the performance measurement practice differs in relation to the companies' size, the respondents were first asked how the companies' performance was evaluated (Table 3).

\begin{tabular}{|c|c|c|c|c|}
\hline $\begin{array}{l}\text { Performance } \\
\text { measurement practices }\end{array}$ & Large & $\begin{array}{l}\text { Medium- } \\
\text { sized }\end{array}$ & Small & $\begin{array}{l}\text { Total } \\
(\% \text { of } \\
\text { total) }\end{array}$ \\
\hline Financial ratios & 12 & 11 & 6 & $\begin{array}{c}29 \\
(17.5 \%)\end{array}$ \\
\hline $\begin{array}{l}\text { Comparison with the } \\
\text { previous year's results } \\
\text { and the plan }\end{array}$ & 20 & 21 & 32 & $\begin{array}{c}73 \\
(44 \%)\end{array}$ \\
\hline $\begin{array}{l}\text { Financial ratios, } \\
\text { comparison with the } \\
\text { previous year's results } \\
\text { and the plan }\end{array}$ & 12 & 10 & 2 & $\begin{array}{c}24 \\
(14.5 \%)\end{array}$ \\
\hline $\begin{array}{l}\text { Financial ratios, } \\
\text { comparison with the } \\
\text { previous year's results } \\
\text { and the plan, and } \\
\text { calculation of variances }\end{array}$ & 11 & 9 & 6 & $\begin{array}{c}26 \\
(16 \%)\end{array}$ \\
\hline Other techniques & 6 & $3^{*}$ & 4 & $13(8 \%)$ \\
\hline Total (\% of total) & $\begin{array}{c}61 \\
(37 \%)\end{array}$ & $54(33 \%)$ & $\begin{array}{c}50 \\
(30 \%)\end{array}$ & $\begin{array}{c}165 \\
(100 \%)\end{array}$ \\
\hline Chi-square test ${ }^{* *}$ & \multicolumn{4}{|c|}{$\mathrm{X}^{2}$-value of $14.032 ; p=0.029$} \\
\hline
\end{tabular}

SOURCE: Own data

Chi-square test ${ }^{* *}$

Notes $^{*}: 2$ middle-sized companies did not provide an answer

Notes $^{* *}: 3$ cells had an expected count less than 5 ; therefore other techniques were excluded from the chi-square test.

On average, the most common technique used is the comparison with the previous year's results and the plan (73 companies out of 165, i.e. $44 \%$ ), followed by financial ratios analysis (17.5\%) and combinations between financial ratios analysis and comparison with the previous year's results, the plan and variances analysis (16\%). Only $14.5 \%$ of the respondents use financial ratios, comparison with the previous year's results and comparison with the plan, and $8 \%$ of respondents use other techniques. The latter are very rarely used. The chisquare tests suggest that the performance measurement system differs between companies of different size $(\mathrm{p}<0.05)$. Small companies do not use financial ratios in the same extent as 
larger companies. They rather use the comparison with previous year results and comparison with the plan. In the case of small companies, even the combination between financial ratios and other techniques is relatively low (14 companies out of 50, i.e. $28 \%$ ).

To understand to what extent the use of financial ratios differs among Slovene companies, we analyzed their use in relation to their content. We based our analysis on a part of ratios defined in the Slovene accounting standards. Different groups of financial ratios were assessed separately. The results are as follows (table 4).

\begin{tabular}{|c|c|c|c|c|c|}
\hline \multicolumn{6}{|c|}{ TABLE $4-$ The use of leverage ratios } \\
\hline & $\begin{array}{l}\text { The use of leverage } \\
\text { ratios }\end{array}$ & Large & $\begin{array}{l}\text { Medium- } \\
\text { sized }\end{array}$ & Small & $\begin{array}{l}\text { Total } \\
(\% \text { of } \\
\text { total) }\end{array}$ \\
\hline & $\begin{array}{l}\text { Use of all ratios defined } \\
\text { by the SAS }\end{array}$ & 46 & 37 & 35 & $\begin{array}{l}118 \\
(73 \%)\end{array}$ \\
\hline & $\begin{array}{l}\text { Use of all ratios defined } \\
\text { by the SAS except } \\
\text { some of them }\end{array}$ & 6 & 8 & 4 & $\begin{array}{c}18 \\
(11 \%)\end{array}$ \\
\hline & $\begin{array}{l}\text { None of these ratios is } \\
\text { used }\end{array}$ & 5 & 9 & 11 & $\begin{array}{c}25 \\
(16 \%)\end{array}$ \\
\hline & Total $(\% \text { of total })^{*}$ & $\begin{array}{l}57 \\
(35.5 \%)\end{array}$ & $54(33.5 \%)$ & $\begin{array}{c}50 \\
(31 \%)\end{array}$ & $\begin{array}{c}161 \\
(100 \%)\end{array}$ \\
\hline & Chi-square test & \multicolumn{4}{|c|}{$\mathrm{X}^{2}$-value of $4.850 ; p=0.303$} \\
\hline
\end{tabular}

Contrary to our expectations, chi-square test did not ascertain any statistical difference between groups of companies. Surprisingly, 35 small companies out of 50 (70\%) use all leverage ratios defined by the SAS. Discrepancies with the results in Table 3 may only refer to a limited use of ratios, primarily the one defining the leverage, neglecting nearly all the others. The majority of the companies in the sample use all leverage ratios defined by the SAS (118 companies or 73\%). Only a small part of the companies state that none of the ratios defined by the SAS is used (25 companies or $16 \%$ ).

Just the opposite is the picture in the case of liquidity ratios (table 5). Chi-square test suggests that the use of liquidity ratios differs between companies of different size $(\mathrm{p}<0.05)$. 


\begin{tabular}{|c|c|c|c|c|}
\hline \multicolumn{5}{|c|}{ TABLE 5 - The use of liquidity ratios } \\
\hline The use of liquidity ratios & Large & $\begin{array}{l}\text { Medium- } \\
\text { sized }\end{array}$ & Small & $\begin{array}{l}\text { Total } \\
\text { (\% of } \\
\text { total) }\end{array}$ \\
\hline $\begin{array}{l}\text { Use of all ratios defined by } \\
\text { the SAS }\end{array}$ & 40 & 22 & 12 & $\begin{array}{c}74 \\
(50 \%)\end{array}$ \\
\hline $\begin{array}{l}\text { Use of all ratios defined by } \\
\text { the SAS } \\
\text { except some of them }\end{array}$ & 8 & 6 & 2 & $\begin{array}{c}16 \\
(11 \%)\end{array}$ \\
\hline None of these ratios is used & 8 & 21 & 29 & $\begin{array}{c}58 \\
(39 \%)\end{array}$ \\
\hline Total $(\% \text { of total })^{\star}$ & $\begin{array}{c}56 \\
(38 \%)\end{array}$ & $49(33 \%)$ & $\begin{array}{c}43 \\
(29 \%)\end{array}$ & $\begin{array}{c}148 \\
(100 \%)\end{array}$ \\
\hline Chi-square test & \multicolumn{4}{|c|}{$\mathrm{X}^{2}$-value of $29.612 ; p=0.000$} \\
\hline
\end{tabular}

SOURCE: Own data

Notes ${ }^{\star}: 3$ companies use other techniques, 16 companies did not provide any answer.

The majority of large companies use all ratios defined by the SAS, while a large extent of medium-sized and small companies ( 21 medium-sized and 29 small companies; i.e. $43 \%$ and $67 \%$, respectively) do not use any of the ratios defined by the SAS. The results for small companies are in line with those resulting from table 3 , where a notable part of small companies seems not to use financial ratios analysis at all. Despite the fact that the majority of small and medium-sized do not use any of the ratios defined by the SAS we believe that companies monitor liquidity in other ways (for instance, see Kavčič, Koželj and Odar, 2010). We believe that medium-sized and small companies do not use the liquidity ratios analysis based on financial ratios defined by the SAS, but they evaluate specific information for decision-makers based primarily upon the needs of the company. In the case of turnover ratios the picture is very similar (Table 6).

\begin{tabular}{|c|c|c|c|c|c|}
\hline & \multicolumn{5}{|c|}{ TABLE 6 - The use of turnover ratios } \\
\hline & $\begin{array}{l}\text { The use of turnover } \\
\text { ratios }\end{array}$ & $\begin{array}{c}\text { Large } \\
\text { companies }\end{array}$ & $\begin{array}{l}\text { Medium- } \\
\text { sized }\end{array}$ & Small & $\begin{array}{l}\text { Total } \\
\text { (\% of } \\
\text { total) }\end{array}$ \\
\hline & $\begin{array}{l}\text { Use of all ratios defined } \\
\text { by the SAS }\end{array}$ & 44 & 27 & 15 & $\begin{array}{c}86 \\
(60 \%)\end{array}$ \\
\hline & $\begin{array}{l}\text { Use of all ratios defined } \\
\text { by the SAS except } \\
\text { some of them }\end{array}$ & 4 & 2 & 1 & $7(5 \%)$ \\
\hline & $\begin{array}{l}\text { None of these ratios is } \\
\text { used }\end{array}$ & 7 & 17 & 27 & $\begin{array}{c}51 \\
(35 \%)\end{array}$ \\
\hline & Total $(\% \text { of total })^{\star}$ & $55(38 \%)$ & $46(32 \%)$ & $\begin{array}{c}43 \\
(30 \%)\end{array}$ & $\begin{array}{c}144 \\
(100 \%)\end{array}$ \\
\hline & Chi-square test** & \multicolumn{4}{|c|}{$\mathrm{X}^{2}$-value of $25.251 ; p=0.000$} \\
\hline
\end{tabular}


The difference between groups of companies is significant. The analysis of results shows that the turnover ratios defined by the SAS are primarily used by large companies, while they are only used in $59 \%$ of medium-sized companies and in $35 \%$ of small companies. The absence of turnover ratios is most notable in small companies as we could speculate on the basis of the results we obtained in Table 3. Interestingly, almost none of the companies uses other techniques that are not defined by the SAS (only 5 companies).

Additionally, we were interested to see to what extent are the financial ratios important for other departments within a company. Table 7 demonstrates that (as expected) large companies pay more attention to financial ratios, as they are also integrated in other departments of the company (58 out of 61 large companies). On the other hand, this is not the case in small companies - only $37 \%$ of cases (18 out of 49 respondents). In this context, medium-sized companies are more similar to large companies than to small companies. In 44 of medium-sized companies ( $80 \%$ of all medium-sized companies) financial ratios are also used by other departments of the company.

\begin{tabular}{|c|c|c|c|c|}
\hline $\begin{array}{l}\text { Use of financial ratios } \\
\text { by other departments }\end{array}$ & Large & $\begin{array}{l}\text { Medium- } \\
\text { sized }\end{array}$ & Small & $\begin{array}{l}\text { Total } \\
\text { (\% of } \\
\text { total) }\end{array}$ \\
\hline They are used & 58 & 44 & 31 & $\begin{array}{c}133 \\
(81 \%)\end{array}$ \\
\hline They are not used & 3 & 11 & 18 & $\begin{array}{c}32 \\
(19 \%)\end{array}$ \\
\hline Total $(\% \text { of total })^{*}$ & $61(37 \%)$ & $55(33 \%)$ & $\begin{array}{c}49 \\
(30 \%)\end{array}$ & $\begin{array}{c}165 \\
(100 \%)\end{array}$ \\
\hline Chi-square test & $\mathrm{X}^{2}$-value of 17 & $p=0.000$ & & \\
\hline
\end{tabular}

SOURCE: Own data

Notes*: 2 companies did not provide an answer.

The use of financial ratios for performance analysis evaluation demonstrates that companies differ in this respect too (Table 8 ). Small companies often make comparative analysis only with previous results and/or with competitors and/or with the branch average (27 out of 47 companies, i.e. 57\%), while large companies more often also rely on the comparison with the planned results (35 out of 61 companies, i.e. 57\%). Medium-sized companies are in this particular case more similar to small compnies. 
TABLE 8 - How is performance analysis evaluated in terms of financial ratios?

Performance analysis evaluation Large Medium- Small $\begin{gathered}\text { Total } \\ \text { sized }\end{gathered}$ total)

Comparative analysis with the previous year's results and/or comparison with competitors and/or comparison with the branch average

Comparative analysis with the planned results **

Comparative analysis with the previous year's results and the planned results and/ or comparison with competitors and/or comparison with the branch average

No answer ${ }^{\star *}$

Total (\% of total $)^{\star}$

$61(37 \%)$

Chi-square test
21

26

5

35

2

20

0

$7(4 \%)$

11

$(41 \%)$
74

$(45 \%)$

66

0
8
9
$16(10 \%)$

$16(10 \%)$

URCE: Own data

Notes ${ }^{*}: 3$ companies use other techniques.

Notes $^{* *}$ : comparative analysis with the planned results and the missing answers were excluded from the chi-square test.

However, the majority of the companies are satisfied with the financial ratios defined by SAS (Table 9). Differences between companies with regard to their size are not significant. The highest share of respondents who think that additional ratios are needed is found among large companies ( 15 companies or $25 \%$ of all large companies). It might seem obvious, as more complex business activities require more sophisticated measurement systems, while small companies are probably satisfied with the extent of ratios included in the SAS, as they often do not calculate many ratios to evaluate performance (deducible from Tables 5 and 6).

TABLE 9 - Usefulness of financial ratios defined by the SAS

\begin{tabular}{lcccc}
$\begin{array}{l}\text { Usefulness of SAS } \\
\text { ratios }\end{array}$ & Large & $\begin{array}{c}\text { Medium- } \\
\text { sized }\end{array}$ & Small & $\begin{array}{c}\text { Total } \\
\text { (\% of } \\
\text { total) }\end{array}$ \\
\hline Satisfies the needs & 45 & 49 & 42 & $\begin{array}{c}136 \\
(84 \%)\end{array}$ \\
$\begin{array}{l}\text { Additional ratios are } \\
\text { needed }\end{array}$ & 15 & 6 & 5 & $\begin{array}{c}26 \\
(16 \%)\end{array}$ \\
$\begin{array}{l}\text { Total (\% of total) } \\
\text { * }\end{array}$ & $60(37 \%)$ & $55(34 \%)$ & $\begin{array}{c}47 \\
(29 \%)\end{array}$ & $\begin{array}{c}162 \\
(100 \%)\end{array}$ \\
Chi-square test & $\mathrm{X}^{2}$-value of 5.668; $p=0.059$ \\
\hline
\end{tabular}

SOURCE: Own data

Notes*: 5 companies did not provide an answer. 
As expected (Table 10), small companies practically never use balanced scorecard systems (only 5 out of 48 companies use them, i.e. 10\%). Large companies, however, use them more often (24 companies out of 59, i.e. 40\%). Medium-sized companies, similar to small companies in large part do not use them (43 companies or $80 \%$ ). Chi-square test affirms our expectations; there is a statistically significant difference between the groups of companies ( $\mathrm{p}$ $<0.05)$.

\begin{tabular}{lcccc}
\multicolumn{4}{l}{ TABLE $10-$ The use of balanced scorecard system } \\
$\begin{array}{l}\text { Balanced } \\
\text { scorecard use }\end{array}$ & Large & $\begin{array}{c}\text { Medium- } \\
\text { sized }\end{array}$ & Small & $\begin{array}{c}\text { Total } \\
\text { (\% of total) }\end{array}$ \\
\hline In use & 24 & 11 & 5 & $40(25 \%)$ \\
Not in use & 35 & 43 & 43 & $121(75 \%)$ \\
$\begin{array}{l}\text { Total } \\
\text { (\% of total) }\end{array}$ & 59 & 54 & 48 & 161 \\
$\begin{array}{l}\text { Chi-square } \\
\text { test }\end{array}$ & $(36.5 \%)$ & $(33.5 \%)$ & $(30 \%)$ & $(100 \%)$ \\
\hline
\end{tabular}

SOURCE: Own data

Notes*: 6 companies did not provide an answer.

Subsequently, we explored which measures are used to evaluate economic performance. Economic performance measures take into account not only the cost of debt but also the cost of capital as traditional accounting measures. The most commonly used measures are following: economic value added (EVA), present value techniques and market value added (MVA). In accordance with the fact that only a small part of large companies is publicly quoted, we formulated our question by including traditional accounting measures and the use of EVA. The results (Table 11) suggest that only large companies use modern economic measures of performance (34 companies out of 60 ; i.e. $57 \%$ ). Medium-sized companies use them in $22 \%$ of cases (12 companies), while small companies in 33\% (15 companies). The difference between companies of different size is significant $(\mathrm{p}<0.05)$. 
TABLE 11 - Economic performance evaluation

\begin{tabular}{|c|c|c|c|c|}
\hline $\begin{array}{l}\text { Economic } \\
\text { performance } \\
\text { evaluation }\end{array}$ & Large & $\begin{array}{l}\text { Medium- } \\
\text { sized }\end{array}$ & Small & $\begin{array}{l}\text { Total } \\
\text { (\% of } \\
\text { total) }\end{array}$ \\
\hline $\mathrm{ROE}$ and/or ROA & 24 & 38 & 29 & $\begin{array}{c}91 \\
(57 \%)\end{array}$ \\
\hline $\begin{array}{l}\text { EVA-Economic } \\
\text { value added } \\
\text { And ROE and/or } \\
\text { ROA }\end{array}$ & 34 & 12 & 15 & $\begin{array}{c}61 \\
(38.5 \%)\end{array}$ \\
\hline Other ${ }^{* *}$ & 2 & 4 & 1 & $7(4.5 \%)$ \\
\hline $\begin{array}{l}\text { Total } \\
(\% \text { of total })^{*}\end{array}$ & \multicolumn{4}{|c|}{$\begin{array}{c}60 \\
(38 \%) \\
54 \\
(34 \%) \\
45(28 \%) \\
159 \\
(100 \%)\end{array}$} \\
\hline Chi-square test & \multicolumn{4}{|c|}{$\mathrm{X}^{2}$-value of $14.336 ; p=0.001$} \\
\hline
\end{tabular}

SOURCE: Own data

Notes ${ }^{\star}: 8$ companies did not provide any answer.

Notes ${ }^{\star *}$ : Other measures were excluded from the chi-square test.

Finally, we were interested to know if any difference can be ascertained by analyzing the performance measurement systems in companies that have their own accounting departments and those that use an external accounting service. We compared all the responses between small companies with internal and external accounting services (the results are presented in appendix). The chi-square test for all the responses suggests that differences between these two groups of companies cannot be found ( $p>0.05)$. In the case of small companies the external accounting service seems to provide as good information as the internal accounting department.

\section{CONCLUSIONS}

Studies have shown that transition and less developed economies have management accounting systems that are less developed than those in traditional market economies (Haldma and Lääts, 2002; Hopper et al., 2009). Focusing on the field of performance measurement, our results suggest that even in the post-transition case of Slovenia, companies rarely use contemporary performance measurement techniques, thus we can accept our first hypothesis. Only a small part of the respondents use balanced scorecard techniques and performance measures apart from those based on traditional accounting measures.

Despite the fact that evolutionary paths of performance measurement were associated with the transition from operations to strategic orientation measures (Chenhall and LangfieldSmith, 1998; Srimai et al., 2011), emphasizing the importance of non-financial measure, the latter were not commonly used in Slovene while over passing the transition process.

A further analysis reveals that performance measurement systems differ between companies of different sizes, confirming previous findings of Garengo, Biazzo and Bititci (2005) and 
suggesting the need for a performance measurement system specific for small and mediumsized companies proposed by Cocca and Alberti (2010). The results of our analysis confirm that the most holistic system of measurement is present in large companies, while less developed systems are used in small companies. Middle-sized companies seem to have more developed measurement systems than small companies, but less developed ones than large companies. Small and medium sized entities usually do not implement integrated performance measurement systems.

Even though the use of financial ratios is almost a business analysis paradigm, small companies do not implement them as we would expect. They seem to prefer simpler techniques, even at the cost of accuracy. We presume that accounting departments in small companies are often engaged only in bookkeeping activities, while further analysis is often missing. Small companies mostly use only leverage ratios, while liquidity ratios and turnover ratios are not that important from their point of view. Small companies should measure their economic performance on some more developed techniques that are not based only on accounting measures (which do not incorporate the equity cost of capital). That is why, further research should engage also in performance measurement frameworks development, since to date no major efforts were made in the field.

Due to a rather small sample of small companies, the results might not reflect the use of financial ratios within the population. We did not include all ratios defined by the SAS, but only the most common ones. The inclusion of additional ratios could lead to different results. Thus, the results we obtained have to be used with prudence. We suppose that the respondents have appropriate knowledge about the content of financial ratios defined by the SAS, and thus were able to provide a fair view of companies' activities.

Future research should analyze further developments of accounting practices in economies that completed the transition process in order to find out to what extent more contemporarily management accounting techniques have been used after the transition.

\section{REFERENCES}

Anderson, Karen and Rodney McAdam. 2004. A critique of benchmarking and performance measurement. Lead or lag? Benchmarking in International Journal 11: 465-483.

Bititci, Umit S., Kepa Mendibil, Sai Nudurupati, Patrizia Garengo and Trevor Turner. 2006. Dynamics of performance measurement and organizational culture. International Journal of Operations \& Production Management 26 (December): 1325-1350.

Bititci, Umit S., Trevor Turner and Carsten Begemann. 2000. Dynamics of performance measurement systems. International Journal of Operations \& Production Management 20: 692-704.

Bourne, Mike, John Mills, Mark Wilcox, Andy Neely, and Ken Platts. 2000. Designing, implementing and updating performance measurement systems. International Journal of Operations and Production Management 20 (July): 754-771.

Braam, Geert J. M., and Edwin J. Nijssen. 2004. Performance effects of using the balanced scorecard: a note on the Dutch experience. Long Range Planning 37 (August): 335-349.

Chenhall, Robert H., and Kim Langfield-Smith. 1998. Adoption and benefits of management accounting practices: an Australian study. Management Accounting Research 
9 (March): 1-19.

Chenhall, Robert H., and Kim Langfield-Smith. 2007. Multiple perspectives of performance measures. European management journal 25 (August): 266-282.

Cocca, Paola, and Marco Alberti. 2010. A framework to assess performance measurement systems in SMEs. International Journal of Productivity and Performance Management 59: 186-200.

Emmanuel, Clive, David Otley, and Kenneth Merchant. 1990. Accounting for management control, London: Chapman and Hill.

Fitzgerald, Lin, Robert Johnston, Stan Brignall, Rhian Silvestro, and Chris Voss. 1991. Performance Measurement in Service Business, CIMA: London.

Garengo, Patriza, Stefano Biazzo, and Umit S. Bititci. 2005. Performance measurement systems in SMEs: A review for a research agenda. International Journal of Management Reviews 7 (March): 25-47.

Haldma,Toomas, and Kertu Lääts. 2002. Contingencies influencing the management accounting practices in Estonian manufacturing companies. Management Accounting Research, 13(December): 379-400.

Hopper, Trevor, Mathew Tsamenyi, Shahzad Uddin and Danture Wickramasinghe. 2009. Management accounting in less developed countries: what is known and what needs knowing. Accounting, Auditing \& Accountability Journal 22: 469-514.

Hudson, Mel, Andi Smart, and Mike Bourne. 2001. Theory and practice in SME performance measurement systems. International Journal of Operations \& Production Management 21: 1096-1115.

Ivankovič, Gordana, Sandra Janković, and Milena Peršić. 2010. Framework for performance measurement in hospitality industry - case study Slovenia. Economic Research 23 (September): 12-23.

Joshi, Prem L. 2001. The international diffusion of new management accounting practices: the case of India. Journal of international accounting, Auditing \& Taxation 10 (Spring): 85109.

Kaplan, Robert S., and David P. Norton. 1992. The Balanced Scorecard: Measures that Drive Performance. Harvard Business Review 70 (January-February): 71-79.

Kavčič, Slavka, Stanko Koželj, and Marjan Odar. 2010. Organization of accounting in Slovene companies. Journal of Auditing 10 (April): 29-63.

Kennerley, Mike, and Andy Neely. 2002. A framework of the factors affecting the evolution of performance measurement systems. International journal of operations \& production management 22 (November): 1222-1245.

Lapointe-Antunes, Pascale, Denis Cormier, and Michel Magnan. 2008. Equity recognition of mandatory accounting changes: the case of transitional goodwill impairment loss 25 (March): 37-54.

Lynch, Richard L., and Cross F. Kelvin. 1991. Measure up!, Cambridge: Blackwell Publishers.

McKinnon, Sharon M., and William J. Bruns. 1992. Management information and accounting information: what do managers want. Advances in Management Accounting 1: 55-80.

Neely, Andy, Chris Adams, and Paul Crowe. 2001. The performance prism in practice. Measuring Business Excellence 5: 6-12.

Neely, Andy. 2005. The evolution of performance measurement research. Developments 
in the last decade and a research agenda for the next. International Journal of Operations \& Production Management. 25 (December): 1264-1277.

Slovene Accounting Standards. 2006. Ljubljana: Slovene Institute of Auditors.

Srimai, Suwit, Jack Radford, and Chris Wright. 2011. Evolutionary paths of performance measurement: an overview of its recent development. International Journal of Productivity and Performance Management 60 (November). Forthcoming.

Stubelj, Igor, and Primož Dolenc. (2010). Fiscal sustainability of EU Member states in the context of current financial crisis. Economic Research 23 (December): 37-62.

Sulaiman, Maliah, Nik N. N. Ahmad, and Norhayati Alwi. 2004. Management accounting practices in selected Asian countries. Managerial Auditing Journal 19 (April): 493-508.

\section{APPENDIX}

\section{THE USE OF LEVERAGE RATIOS}

\begin{tabular}{lccc} 
The use of leverage ratios & $\begin{array}{c}\text { Internal } \\
\text { accounting } \\
\text { service }\end{array}$ & $\begin{array}{c}\text { External } \\
\text { accounting } \\
\text { service }\end{array}$ & $\begin{array}{c}\text { Total } \\
\text { (\% of } \\
\text { total) }\end{array}$ \\
\hline $\begin{array}{l}\text { Use of all ratios defined } \\
\text { by the SAS }\end{array}$ & 27 & 8 & $35(70 \%)$ \\
$\begin{array}{l}\text { Use of all ratios defined } \\
\text { by the SAS except some } \\
\text { of them }\end{array}$ & 2 & 2 & $4(8 \%)$ \\
$\begin{array}{l}\text { None of these ratios is } \\
\text { used }\end{array}$ & 8 & 3 & $11(22 \%)$ \\
$\begin{array}{l}\text { Total (\% of total) } \\
\text { Chi-square test }\end{array}$ & $37(74 \%)$ & $13(26 \%)$ & $\begin{array}{c}50 \\
(100 \%)\end{array}$ \\
& $\begin{array}{l}\mathrm{X}^{2} \text {-value of } \\
1.386 ; p= \\
0.500\end{array}$ & & \\
\hline
\end{tabular}




\section{THE USE OF LIQUIDITY RATIOS}

SOURCE: Own data

\begin{tabular}{lccc} 
The use of liquidity ratios & $\begin{array}{c}\text { Internal } \\
\text { accounting } \\
\text { service }\end{array}$ & $\begin{array}{c}\text { External } \\
\text { accounting } \\
\text { service }\end{array}$ & $\begin{array}{c}\text { Total } \\
\text { (\% of } \\
\text { total) }\end{array}$ \\
\hline $\begin{array}{l}\text { Use of all ratios defined by } \\
\text { the SAS }\end{array}$ & 8 & 4 & $\begin{array}{c}12 \\
(27.9 \%)\end{array}$ \\
$\begin{array}{l}\text { Use of all ratios defined by } \\
\text { the SAS } \\
\text { except some of them }\end{array}$ & 2 & 0 & $2(4.7 \%)$ \\
$\begin{array}{l}\text { None of these ratios is used } \\
\text { Total (\% of total)* }\end{array}$ & 22 & 7 & $\begin{array}{c}29 \\
\text { Chi-square test }\end{array}$ \\
\hline
\end{tabular}

Notes ${ }^{\star} 7$ companies did not provide any answer.

\section{THE USE OF TURNOVER RATIOS}

\begin{tabular}{|c|c|c|c|}
\hline The use of turnover ratios & $\begin{array}{l}\text { Internal } \\
\text { accounting } \\
\text { service }\end{array}$ & $\begin{array}{l}\text { External } \\
\text { accounting } \\
\text { service }\end{array}$ & $\begin{array}{l}\text { Total } \\
\text { (\% of } \\
\text { total) }\end{array}$ \\
\hline $\begin{array}{l}\text { Use of all ratios defined by } \\
\text { the SAS }\end{array}$ & 12 & 3 & $\begin{array}{c}15 \\
(35.7 \%)\end{array}$ \\
\hline None of these ratios is used & 18 & 9 & $\begin{array}{c}27 \\
(64.3 \%)\end{array}$ \\
\hline Total $(\% \text { of total })^{\star}$ & $30(71.4 \%)$ & $12(28.6 \%)$ & $42(100 \%)$ \\
\hline Chi-square test & $\begin{array}{c}\mathrm{X}^{2} \text {-value of } \\
0.840 ; p= \\
0.359\end{array}$ & & \\
\hline
\end{tabular}

SOURCE: Own data

Notes*: 1 company uses other techniques, 7 companies did not provide any answer.

\section{ARE FINANCIAL RATIOS ALSO USED BY OTHER DEPARTMENTS OF THE COMPANY?}

Use of financial ratios by Internal accounting External accounting service other departments service

\begin{tabular}{lccc}
\hline They are used & 24 & 7 & $31(63.3 \%)$ \\
They are not used & 13 & 5 & $18(36.7 \%)$ \\
Total $(\%$ of total) & $37(75.5 \%)$ & $12(24.5 \%)$ & $49(100 \%)$ \\
Chi-square test & & $\mathrm{X}^{2}$-value of $0.166 ; p=0.683$ & \\
\hline
\end{tabular}

SOURCE: Own data

Notes $^{\star}: 1$ company did not provide any answer. 


\section{HOW IS PERFORMANCE ANALYSIS EVALUATED IN TERMS OF FINANCIAL RATIOS?}

Performance analysis evaluation

\begin{tabular}{ccc}
$\begin{array}{c}\text { Internal } \\
\text { accounting } \\
\text { service }\end{array}$ & $\begin{array}{c}\text { External } \\
\text { accounting } \\
\text { service }\end{array}$ & $\begin{array}{c}\text { Total } \\
\text { (\% of } \\
\text { total) }\end{array}$ \\
\hline 20 & 7 & $\begin{array}{c}27 \\
(71.1 \%)\end{array}$ \\
10 & 1 & $\begin{array}{c}11 \\
(28.9 \%)\end{array}$ \\
$30(78.9 \%)$ & $8(21.1 \%)$ & $\begin{array}{c}38 \\
(100 \%)\end{array}$
\end{tabular}

Chi-square test

$\mathrm{X}^{2}$-value of $1.333 ; p=0.248$

SOURCE: Own data

Notes $* 3$ companies use other techniques.

Notes $^{* *}$ : 9 companies did not provide any answer.

\section{USEFULNESS OF FINANCIAL RATIOS DEFINED BY THE SAS}

\begin{tabular}{lccc} 
Usefulness of SAS ratios & $\begin{array}{c}\text { Internal } \\
\text { accounting } \\
\text { service }\end{array}$ & $\begin{array}{c}\text { External } \\
\text { accounting } \\
\text { service }\end{array}$ & $\begin{array}{c}\text { Total } \\
(\% \text { of } \\
\text { total) }\end{array}$ \\
\hline Satisfies the needs & 32 & 10 & $\begin{array}{c}42 \\
(89.4 \%)\end{array}$ \\
$\begin{array}{l}\text { Additional ratios are } \\
\text { needed }\end{array}$ & 5 & 0 & 5 \\
$\begin{array}{l}\text { Total (\% of total)* } \\
\text { Chi-square test }\end{array}$ & $37(78.7 \%)$ & $10(21.3 \%)$ & $\left.\begin{array}{c}47 \\
(10 \% \%)\end{array}\right)$ \\
& $\mathrm{X}^{2}$-value of $1.512 ; p=0.219$
\end{tabular}

SOURCE: Own data

Notes ${ }^{*}: 3$ companies did not provide any answer.

\section{THE USE OF BALANCED SCORECARD SYSTEM}

\begin{tabular}{lccc}
$\begin{array}{l}\text { Balanced } \\
\text { scorecard use }\end{array}$ & $\begin{array}{c}\text { Internal } \\
\text { accounting } \\
\text { Service }\end{array}$ & $\begin{array}{c}\text { External } \\
\text { accounting } \\
\text { service }\end{array}$ & $\begin{array}{c}\text { Total } \\
\text { (\% of total) }\end{array}$ \\
\hline In use & 4 & 1 & $5(10.4 \%)$ \\
Not in use & 33 & 10 & $43(89.6 \%)$ \\
Total (\% of total) & $37(77.1 \%)$ & $11(22.9 \%)$ & $48(100 \%)$ \\
Chi-square test & \multicolumn{4}{c}{$\mathrm{X}^{2}$-value of $0.027 ; p=0.870$} \\
\hline
\end{tabular}

SOURCE: Own data

Notes: 2 companies did not provide any answer. 


\section{ECONOMIC PERFORMANCE EVALUATION}

\begin{tabular}{lccc}
$\begin{array}{l}\text { Economic performance } \\
\text { evaluation }\end{array}$ & $\begin{array}{c}\text { Internal } \\
\text { accounting } \\
\text { service }\end{array}$ & $\begin{array}{c}\text { External } \\
\text { accounting } \\
\text { service }\end{array}$ & $\begin{array}{c}\text { Total } \\
\text { (\% of } \\
\text { total) }\end{array}$ \\
\hline ROE and/or ROA & 21 & 8 & $\begin{array}{c}29 \\
(65.9 \%)\end{array}$ \\
$\begin{array}{l}\text { EVA-Economic value } \\
\text { added } \\
\text { and ROE and/or ROA* }\end{array}$ & 12 & 3 & $\begin{array}{c}15 \\
\text { Total (\% of total) }\end{array}$ \\
$\begin{array}{l}\text { Chi-square test } \\
\text { (** }\end{array}$ & $33(75 \%)$ & $11(25 \%)$ & $\left.\begin{array}{c}44 \\
(100 \%)\end{array}\right)$ \\
\hline
\end{tabular}

SOURCE: Own data

Notes $^{*}: 5$ companies did not provide an answer.

Notes ${ }^{\star *}$ : Other measures were excluded from the chi-square test (1 company).

\section{SISTEMI MJERENJA PERFORMANSI: EMPIRIJSKI DOKAZI IZ SLOVENIJE}

\section{SAŽETAK}

Cilj ovog rada je analiza korištenja sistema mjerenja performansi u velikim, srednjim $i$ malim slovenskim poduzećima. Istraživanje je provedeno na temelju ankete koja je podijeljena menadžmentu slovenskih tvrtki u 2007. Istraženo je korištenje tehnika mjerenja peformansi u post-tranzicijskom periodu. Slovenske tvrtke uglavnom koriste tradicionalne tehnike mjerenja performansi. Suvremeni sistemi mjerenja performansi su se koristili samo povremeno. Osim toga, istraživanje dokazuje kako se tehnike mjerenja performansi razlikuju među tvrtkama različite veličine. Male tvrtke imaju manje razvijene sisteme mjerenja performansi koji se zasnivaju gotovo isključivo na tradicionalnim tehnikama mjerenja, dok velike tvrtke imaju razvijenije sisteme mjerenja performansi te se također koriste i nekim suvremenim tehnikama. Buduća istraživanja bi trebala analizirati strukturu sistema upravljačkog računovodstva u ekonomijama koje su dovršile tranzicijski period kako bi se dobili dokazi o promjenama koje se događaju nakon toga.

Ključne riječi: sistem mjerenja performansi, sistem upravljačkog računovodstva, tranzicijska ekonomija. 
Economic Research - Ekonomska istraživanja, Vol. 25 (2012) No. 2 (445-464) 